\title{
CONSUMERS' PERCEPTION OF FOOD QUALITY AND SAFETY IN TERMS OF BUYING PROCESSES
}

\author{
Monika STOMA, Agnieszka DUDZIAK, Tomasz SŁOWIK, \\ Jacek WASILEWSKI, Andrzej KURANC \\ University of Life Sciences in Lublin, POLAND \\ E-mail of corresponding author: monika.stoma@up.lublin.pl
}

Keywords: food quality and safety, buying processes, consumers' perception, sustainable agriculture, sustainable consumption

\begin{abstract}
Food safety and quality is a global and multidisciplinary notion that has an impact upon both food industry companies and consumers. Sustainable agriculture and consumption are not currently just fashion, and the consumer relationship with the product is very important because it is not enough to produce responsibly consumer awareness of the production should also be increased. A consumer deciding to choose a specific product should be aware of why he has made a purchase. There are many determinants that can convince him for specific products; some of them are quality and safety. These two issues seem to be inextricably linked to the idea of sustainable development. Nowadays consumers' awareness of food products choices is noticeably rising, thereby the study aims at researching and assessing consumers' perception of food quality and safety and the related impact upon buying processes. The results arising from the study have made it plausible to state that contemporary consumers perceive themselves as individuals who are aware of safety and quality of food products they buy, and top quality food is associated by them most of all with the lack of preservatives, quality certificates, and a producer's assurance that a food product is $100 \%$ organic.
\end{abstract}

\section{INTRODUCTION}

Food serves the basis for human existence and has a direct and considerable either positive or adverse impact upon health condition. According to Stewart (1987): „Diet (...) is the major source of nutrients but it may be the substantial source of hazards arising from infectious, toxic, and pharmacologic substance". Thus, food quality and safety is essential for consumers, food and agriculture industry companies as well as the economy as a whole.

As far as consumers are concerned, awareness of food safety and quality is noticeably rising and in consequence the awareness of related processes and buying choices is rising, too. On the other hand, food producers are characteristic of top quality and safety food assurance systems and food standard compliance systems, that are becoming top priorities. It is so important for a food product quality, that reaches the final consumer, to be the outcome of various factors and processes undertaken by a food producer; the following is of utmost importance: quality of raw food ingredients used for food production purposes, food production technology, application of relevant additives, selection of sub-operations, and choice of adequate process parameters (Nowak 2011). Nowadays this issue is becoming more and more significant, on the one hand, due to a high growth rate of the food industry and mass food production technological advancement and globalisation process, and on the other hand - due to intensive education of society in the area of food products safety and related impact upon human health and conduct as well as natural environment.

Food safety and quality is the global, multidisciplinary and multidimensional; notion addressing both collective and individual features. Thereby they are hard to be defined in an unbiased manner - especially in terms of quality. However, the related literature includes a number of attempts to address that issue; some of the authors reckon that food 
products quality may be analysed mainly in terms of technical, mental, and marketing aspect, which first of all means the degree of wholesomeness (dietary value, energy value, nutritious value, and health safety), sensoric attractiveness (for instance, shape, size, hue, taste, scent, consistence, texture) and disposability (food product sustainability, easy-touse food, easy-to-prepare food, etc.). By contrast, food products safety is based on 4 fundamental pillars - the so-called safety criteria, namely: physical, chemical, microbiological, and information safety.

Consumers' perception and assessment of food products quality is subjective, however, Gutman (1982) has drawn attention to 3 major approaches: information economics approach, hierarchical approach, and integrated approach. According to Karaszewski (2006), a buyer perceives quality through the prism of various factors, for example, production quality, affordable price, sustainability, usability, accessibility, easy-to-use, etc. Furthermore, Kijowski and Wysłouch (2003) state that a consumer cannot assess food quality at the moment of buying food products; a consumer's choice is driven only by sensory perception indicators. These are the food producers, that are accountable for food products safety and quality, inter alia, by means of implementation of effective quality management and assurance systems, and state authorities - by means of enforcement of relevant food law and related regulations as well as appointment of supervisory bodies.

Thus, the study aims at researching and assessing consumers' perception of food quality and safety and the related impact upon buying processes, with particular regard to aspects of producer responsibility for the goods they manufacture. An increasing number of consumers is paying attention to the way goods are produced, whether they are produced according to responsible business policy, respect for animals, plants, lack of waste, and, for example, the philosophy of the FAIRTRADE brand, with respect for human dignity, decent pay for work, appropriate social conditions and transparent business relationships between partners. These are important issues, especially decisive for the purchase choice among an increasing number of consumers.

\section{MATERIAL AND METHODS}

A questionnaire survey, in which 200 people participated, was conducted in order to assess consumers' food quality and safety and related impact upon buying choices. Random sampling was applied - simple random sampling formula (without replacement). The questionnaire survey was conducted in 2016.

The survey questionnaire was used as the survey tool, that had been designed deliberately for the purpose of this study. It contained closed-ended questions that had been formulated in such a way as to avoid supplementary comments.

For the purpose of demographic and social characteristics of the surveyed population, the questionnaire was supplemented with an annex that included questions, inter alia, about sex and age. 95 men (accounting for $44 \%$ of the surveyed population) and 121 women $(56 \%)$ participated in the questionnaire survey. $4 \%$ respondents were not older than 18 years old, $59 \%$ - at the age ranging from 19 to 25 years old, $18 \%$ - at the age ranging from 26 to 35 years old, $12 \%$ - at the age ranging from 35 to 55 years old and $7 \%$ - at the age above 56 years old.

\section{RESEARCH RESULTS AND DISCUSSION}

For the purpose of achieving the study objective, the results of the questionnaire survey were analysed and elaborated upon in the descriptive and graphic form (Fig. 1). 
Those surveyed were requested to define the notion ",high quality food" - they had 10 answers to choose from, and could choose not more than 3 answers. As it has turned out, the majority of contemporary consumers associate high quality food with the lack of preservatives ( $84 \%$ response rate), quality certificate (74\%) and a producer's assurance that a food product is $100 \%$ organic, which means that it has been produced by an organic food farm in conformity with organic food production standards - without artificial fertilizers, chemical plant protection products, and antibiotics - in compliance with high quality standards (52\%). It also bears noting that high quality food is rather associated with food products of Polish origin (38\%) and not with food products produced abroad (1\%). Consumers do not associate high quality food with modern packaging at all (0\% response rate) and rarely associate them with long best before dates (6\%), well renowned brands $(8 \%)$ and high prices $(9 \%)$. That may prove that well known producers, modern packaging or high prices are not necessarily the factors that account for a high quality food product.

Respondents were subsequently asked which packing marks convince them most of safety and good quality of a food product they had bought. That question was alike the previous ones. The obtained results have allowed to confirm the previously received information - the marks, that correlate with the proven food safety and quality, are regarded as: „No Preservatives” (65\% response rate), „Natural Ingredients Only” (48\%), „100\% Organic Product” (36\%), „Polish Product” (30\%) „Top Quality Ingredients” $(24 \%)$.

Due to the fact that consumers declared the top quality food was influenced by the certification procedures to a great extent, they were asked subsequent questions concerning the food safety and quality assurance systems. Unfortunately, respondents' knowledge of that was not best as $31 \%$ of them declared not to know any of the systems referred to in the question. Other persons regarded the following as the most significant to guarantee top quality and safety food: HACCP System (45\% response rate), GHP/GMP (Good Hygienic Practice/Good Manufacturing Practice) - 25\% as well as ISO 2200 standard $(11 \%)$.

The resulting figures confirm the conclusions arrived at in result of the survey on food product consumers' perception of food quality and safety and recognition of quality marks and certificates as conducted by other authors. Grębowiec obtained similar results (2015) - the following systems turned out to be best known among consumers: HACCP, ISO 9001 and ISO 22000, and less known - IFS and BRC standards. Whereas as many as $37,5 \%$ of respondents had never heard of any of those systems.

Issanchou (1996) or Wilcock et al. (2004) also indicated the need for further intensive consumers' awareness raising after having obtained their results - especially food product consumers - by means of professional education and reliable information. It bears noting, however, that knowledge on health is noticeably improving amongst Polish contemporary consumers, which in consequence causes knowledge on nutrition and rational diet to improve in result of the health education of society (Grzybowska-Brzezińska 2010). It seems to reflect general trends in the global food market.

According to Szwacka-Mokrzycka (2013) and Grębowiec (2015), factors, that precondition buyers' choices, include economic, marketing, social, and psychological factors. However, in the food product market in Poland, especially those food products that satisfy the basic needs of a human body, economic factors (most of all a product price 
and disposable income per household member) and social factors (nutrition customs and habits) count most. In the contemporary food market marketing factors are also important determinants such as: skillful product policy (diversified product offer, product packaging), price policy and publicity measures. However, it bears noting that consumers' buying choices cover a system of cohesive responses related to decision making and normally result from the influence of the aforementioned determinants upon buyers' choices - the influence being varied and aiming at varied targets.

Thus, in order to study determinants that pre-condition food buyers' choices, subsequent questions were asked to respondents, to what extent they took into consideration the following factors in the course of buying food: packing marks referring to quality, ingredients, best before dates, price, brand, promotion, friends' opinions, others - which out of those they considered to be the most important and which ones did not influence buying processes at all. Analyses of the results were conducted on the grounds of the gender grouping variable (Fig. 1). Identification of criteria that consumers follow in the process of market decision making allow food industry companies to prepare a tailored product offer satisfying consumers' expectations and preferences (Augustyńska-Prejsnar 2014) and the very consumers - to avoid or mitigate risks of bad choices in the process of buying, which is reflected not only in economic but also social affairs (for instance, in health care).

a)

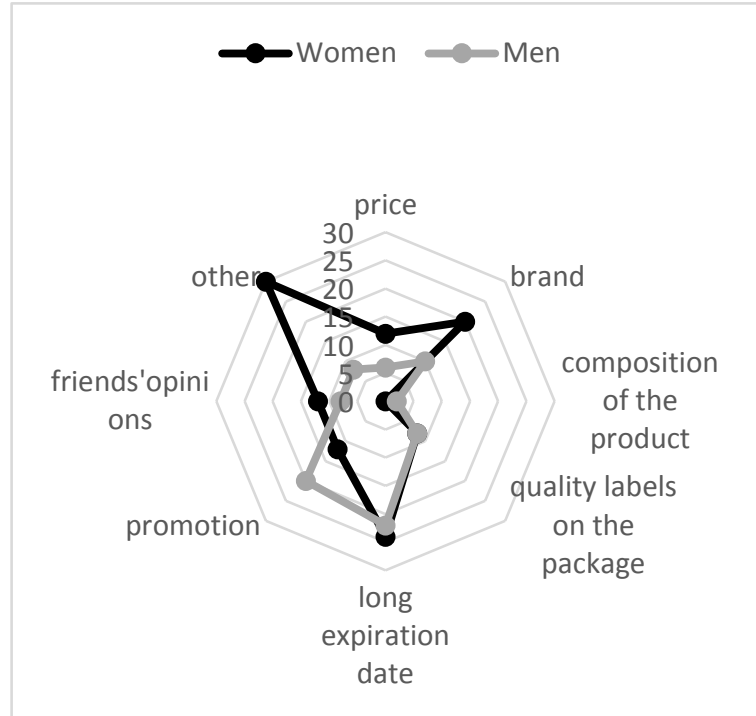

b)

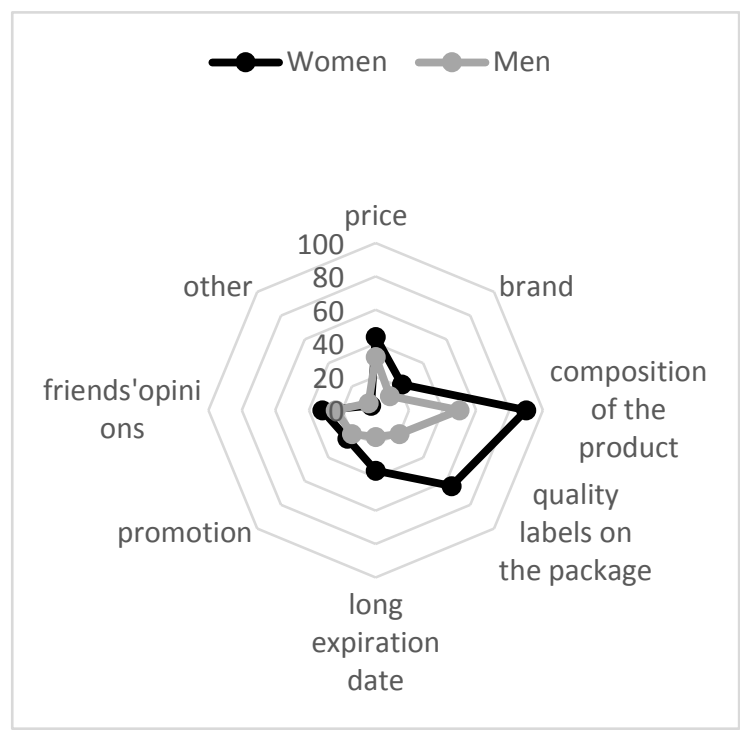

Fig. 1. Buyer's choice factors in consumers' opinion: a) key, b) least important

According to the figures presented by means of the Figure 1, respondents notwithstanding they indicated in response to the previous questions that both food quality and food safety mattered to them and that they paid attention to food product packing marks - they regarded the following buyers' choice factors as the most important ones: among other factors that had not been referred to in the question, long best before sates, and brands (female), and additionally promotion (male). On the other hand, they regarded the following factors as the least important in the course of food product buying decisions: ingredients price, and packing quality (for both women and men). 


\section{CONCLUSIONS}

The results arising from the study have made it plausible to state that contemporary consumers perceive themselves as individuals who are aware of safety and quality of food products they buy, and top quality food is associated by them most of all with the lack of preservatives, quality certificates, and a producer's assurance that a food product is $100 \%$ organic. Whereas it is not necessarily associated with a well-known producer, modern packaging or high price. Furthermore, consumers have declared that they pay attention to packing marks, especially those referring to food safety and quality (for instance, „No Preservatives”, „Natural Ingredients Only” or „100\% Product Organic”) since they repeatedly convince to make buying choices. Although consumers associate top food quality with inter alia quality-certified food, they are not too familiar with food quality and safety assurance and management systems - almost $1 / 3$ of the surveyed are not familiar with any of those systems. However, the HACCP system has turned out to be most well identified.

The study results have also made it plausible to state that notwithstanding the fact that contemporary consumers consider themselves to be aware of food safety and quality, they pay attention mostly to brands, long best before dates, and promotion when making decisions to buy food products whereas quality and safety, namely: ingredients or product marks do not matter much to them in the course of buying processes. That is indicative of the need for further intensive health education of society and awareness rising to the extent of health, diet, consumers' choices and sustainable consumption.

\section{REFERENCES}

Augustyńska-Prejsnar, A., Ormian, M., \& Gajdek G. (2014). Wybory rynkowe mięsa kurcząt brojlerów w opinii studentów. Journal of Agribusiness and Rural Development, 3(33), 5-13.

Górecka-Brzezińska, M. (2010). Uwarunkowania zmian zachowań konsumentów na rynku żywności. Zesz. Nauk. Uniwersytetu Szczecińskiego, Probl. Zarz. Finan. Mark., 609(16), 309-320.

Grębowiec, M. (2015). Rola jakości w podejmowaniu decyzji nabywczych przez konsumentów na przykładzie rynku mięsa i wędlin. J. Agribus. Rural Dev., 1(35), 39-47.

Gutman, J. (1982). A means and chain model based on consumer categorization processes. J. Mark., 46(2).

Issanchou, S. (1996). Consumer expectations and perceptions of meat and meat product quality. Meat Sci., 43, 5-19.

Karaszewski, R. (2006). Nowoczesne koncepcje zarządzania jakością. Toruń: TNOiK Dom Organizatora.

Kijowski, J., Wysłouch, W. (2003). Integracja system HACCP i systemu według normy PN-EN ISO serii 9000:2001. [in:] Kijowski, J., Sikora, T. (2003). Zarządzanie jakością i bezpieczeństwem żywności. Integracja i informatyzacja systemów. Warszawa: WNT.

Nowak, D. (ed.) (2011), Jakość, bezpieczeństwo żywności - kształtowanie jakości żywieniowej w procesach technologicznych. Wyd. SGGW. Warszawa 2011.

Stewart, K. (1987). On reasons for a new journal. Journal of Food Composition and Analysis, 1(1), 1-2.

Szwacka-Mokrzycka, J. (2013). Tendencje rozwojowe popytu i podaży żywności w Polsce, Wyd. SGGW, Warszawa.

Wilcock, A., Pun, M., Khanona, J., \& Aung, M. (2004). Consumer attitudes, knowledge and behavior: a review of food safety issues. Trends Food Sci. Technol., 15, 56-66. 